\title{
ЕФЕКТИВНІСТЬ ЗАСТОСУВАННЯ МЕТОДІВ ФІЗИЧНОЇ РЕАБІЛІТАЦІЇ ДЛЯ ДІТЕЙ 3 ДИТЯЧИМ ЦЕРЕБРАЛЬНИМ ПАРАЛІЧЕМ: БІБЛІОМЕТРИЧНИЙ АНАЛІЗ
}

\author{
М. Д. Семенець, I. P. Мисула, Т. Г. Бакалюк, А. В. Семенець \\ Тернопільський національний медичний університет \\ імені І. Я. Горбачевського МОЗ Украӥни
}

\begin{abstract}
Проведено бібліометричний аналіз наукових робіт у каталозі бібліотеки PubMed, які містять дані щодо ефективності застосування методів фізичної реабілітації для дітей з дитячим церебральним паралічем. Показано, що дані метааналізу та систематичних оглядів з цієї проблеми свідчать про ефективність застосування методів фізичної реабілітації для дітей з дитячим церебральним паралічем. Необхідним $€$ застосування числових шкал (GMFCS, GMFM) для кількісної оцінки ефективності процесу фізичної реабілітації.
\end{abstract}

\section{PHYSICAL REHABILITATION METHODS EFFECTIVENESS FOR CHILDREN WITH CEREBRAL PALSY: A BIBLIOMETRIC ANALYSIS}

\author{
M. D. Semenets, I. R. Mysula, T. G. Bakalyuk, A. V. Semenets \\ I. Horbachevsky Ternopil National Medical University
}

A bibliometric analysis of scientific papers on the topic of physical rehabilitation methods effectiveness for children with cerebral palsy available in PubMed is performed. Publications containing the results of metaanalysis and systematic reviews are studied. Effectiveness of physical rehabilitation methods for children with cerebral palsy is confirmed. It is admitted that numerical assessment methods (GMFCS, GMFM) usage is strongly required.

Вступ. В Україні спостерігається тенденція до зростання кількості дітей із захворюваннями, які супроводжуються синдромом рухових порушень [1]. Одним із найпоширеніших рухових розладів у дітей є дитячий церебральний параліч (ДЦП), який спостерігають з частотою від 2 до 3,3 на 1000 новонароджених [1]. ДЦП є узагальненим терміном для групи захворювань, що проявляються передусім порушеннями рухів, рівноваги та положення тіла. Спастична диплегія - найпоширеніша форма ДЦП, спричиняється порушенням розвитку мозку або ушкодженням одного чи декількох його відділів, що контролюють м'язовий тонус та моторну активність (рухи). Діти зі спастичною диплегією переважно відстають у своєму моторному розвитку і пізніше досягають таких його ланок, як перевертання, сидіння, повзання та ходьба. Незважаючи на досягнення сучасної медицини, спастична диплегія залишається складною проблемою. Кількість дітей з цим діагно- зом збільшується в усьому світі. Тому доцільно використовувати програми фізичної терапії та ерготерапії з застосуванням нових методів реабілітації дітей даної категорії.

Таким чином, метою роботи стало проведення бібліометричного аналізу наукових робіт у каталозі бібліотеки PubMed, які містять дані щодо ефективності застосування методів фізичної реабілітації для дітей з ДцП.

Проаналізували наукові публікації на тему терапії та/або реабілітації при ДцП, зареєстровані в бібліотеці PubMed (https://pubmed.ncbi.nlm.nih.gov/) протягом 2 років (до 1 липня 2021 р.). Усього знайдено 773 наукові роботи, 123 з яких класифіковані PubMed як метааналіз або систематичний огляд. Після ознайомлення зі змістом вказаних робіт, для детального вивчення відібрано 10 публікацій, які наведені нижче, що містять результати метааналізу та систематичних оглядів із цієї проблеми. 
Основна частина. У роботах [2-4] узагальнено ефективність всіх видів фізичної терапії при реабілітації дітей з дцП. Зокрема, метааналіз X. Liang et al. [2] ґрунтується на даних 27 клінічних випробувань (834 пацієнти дитячого віку з ДЦП), що були представлені в бібліотеках PubMed, Embase та Cochrane Library станом на січень 2020 р. Результати метааналізу, проведеного X. Liang et al., вказують на позитивний вплив від виконання вправ фізичної терапії на швидкість ходьби ( $p=0,032$ за даними 16 публікацій) та тонус м'язів ( $p=0,013$ за даними 17 публікацій), але, одночасно, на відсутність значущого загального ефекту за шкалою GMFCS ( $p=0,302$ за даними 17 публікацій). У дослідженні [3] з метою оцінки ефективності застосування курсів фізичної реабілітації для покращення загальної рухової моторики (Gross Motor Activity) у пацієнтів із дцП оброблено дані 36 досліджень (1264 пацієнти дитячого віку 3 ДцП) за період 15 років (до 2018 р.). У висновках G. Clutterbuck et al. показано високу ефективність курсів фізичної реабілітації (Evidence Level II-IV за шкалою PRISMA для 17 публікацій). При цьому автори наголошують на необхідності персоналізації терапії.

Важливе значення для дітей з дЦП має системний підхід до реабілітації, що не може обмежуватися лише амбулаторними заняттями. Однак лише одне узагальнююче дослідження було знайдено: L. Beckers et al. [4], здійснено спробу оцінки ефективності застосування домашніх програм фізичної реабілітації хворих на ДцП на основі даних 92 публікацій (до 2019 р.) Робота підтверджує високу актуальність нерозривності процесу фізичної реабілітації. Проте автори зазначають мало робіт, що містять кількісні оцінки ефективності процесу фізичної реабілітації.

На сьогодні розроблено значну кількість методик лікування та фізичної реабілітації дітей з дцп. Важливими $\epsilon$ дослідження, що мають на меті оцінку ефективності застосування окремих методик. Роботи $[5,6]$ аналізують вплив реабілітаційних методик, що ґрунтуються на обмеженні певних рухів (Resistance Therapy, Constraint-Induced Movement Therapy) та призначені для стимулювання компенсаторних функцій нервової системи. При цьому немає єдиної думки щодо поліпшення рухових функцій в результаті тренування м'язової сили у пацієнтів із ДцП. Порівнюючи дані Gross Motor Function Measure (GMFM) з 15 клінічних випробувань, L. Collado-Garrido et al.
[5] встановлено наявність суттєвого ефекту $(p<0,001)$ даного типу фізичної терапії на загальну рухову моторику при дЦП. Однак ширший аналіз B. Hoare et al. [6], що ґрунтується на даних 36 клінічних випробувань (1264 пацієнти), не показав надійної відмінності в ефективності застосування обмежувальної терапії порівняно з іншими методиками фізичної реабілітації.

Іншим прикладом сучасної методики фізичної реабілітації при дцП $\epsilon$ іпотерапія. За результатами систематичного огляду [7] (ґрунтується на даних 10 клінічних досліджень, що охоплюють 452 пацієнти), L. Guindos-Sanchez et al. показано наявність суттєвого впливу даної реабілітаційної методики на загальну рухову моторику при дцП (SMD=0,81 для GMFM-66, SMD: 0,64; 0,42 та 0,40 для GMFM-88 dimension A/B/E відповідно).

Велике значення при роботі з дітьми з ДЦП мають мотиваційні та психологічні аспекти. Дослідження $[8,9]$ аналізують ефект від застосування сучасних інформаційних технологій (інтерактивні тренажери та обладнання «віртуальної реальності») в процесі фізичної реабілітації дітей з дцп. Незважаючи на відмінності в оцінках, J. V. Fandim et al. [9], виходячи з даних 38 публікацій, вказують на відсутність значущого ефекту застосування VR-технологій, порівняно зі звичайними заняттями, тоді як Z. Ren, \& J. Wu [8], на основі даних 7 клінічних досліджень, вказують на наявність такого впливу - особистий досвід авторів також підтверджує позитивний терапевтичний ефект застосування сучасних ігрових технологій на заняттях із фізичної реабілітації.

Важливим завданням $\epsilon$ оцінка ефективності застосування Action Observation Training у фізичній реабілітації дітей з дцП, оскільки, ґрунтуючись на техніках обмеження рухомості (Resistance Therapy, Constraint-Induced Movement Therapy), дана методика передбачає застосування мультимедіа- та інформаційних технологій. Аналогічно до попереднього випадку, наявні систематичні огляди $[10,11]$ підтверджують загальний прогрес пацієнтів, але не дають однозначної відповіді щодо ефективності саме застосування мультимедіа- та інформаційних технологій.

Висновки. Дитячий церебральний параліч $є$ одним із найпоширеніших рухових розладів у дітей. Фізична терапія відіграє важливу роль в процесі лікування та реабілітації таких хворих. Бібліометричні дані наукових публікацій, що представлені в бібліотеках PubMed, Embase та Cochrane Library та містять 
результати метааналізу та систематичних оглядів, свідчать про те, що фізична терапія $\epsilon$ ефективною при реабілітації дітей з ДцП. Оцінку ефективності фізичної реабілітації при ДцП доцільно здійснювати за допомогою кількісних шкал, зокрема GMFCS

\section{СПИСОК ЛІТЕРАТУРИ}

1. Заклади охорони здоров'я та захворюваність населення України у 2018 році : статистичний бюлетень // Держкомстат України. - К., 2019. - 36 с.

2. Effectiveness of exercise interventions for children with cerebral palsy: A systematic review and meta-analysis of randomized controlled trials / X. Liang, Z. Tan, G. Yun [et al.] // Journal of rehabilitation medicine. - 2021. - Vol. 53, No. 4. - P. jrm00176. https://doi.org/10.2340/16501977-2772.

3. Clutterbuck G. Active exercise interventions improve gross motor function of ambulant/semi-ambulant children with cerebral palsy: a systematic review / G. Clutterbuck, M. Auld, L. Johnston // Disability and rehabilitation, - 2019. Vol. 41, No. 10. - P. 1131-1151. https://doi.org/10.1080/096 38288.2017.1422035.

4. Feasibility and effectiveness of home-based therapy programmes for children with cerebral palsy: a systematic review / L. Beckers, M. Geijen, J. Kleijnen // BMJ open. 2020. - Vol. 10, No. 10. - P. e035454. https://doi.org/10.1136/ bmjopen-2019-035454.

5. Impact of Resistance Therapy on Motor Function in Children with Cerebral Palsy: A Systematic Review and Meta-Analysis / L. Collado-Garrido, Parás- P. Bravo, P. CalvoMartín, M. Santibáñez-Margüello // International journal of environmental research and public health. - 2019. - Vol. 16, No. 22. - P. 4513. https://doi.org/10.3390/ijerph16224513.

6. Constraint-induced movement therapy in children with unilateral cerebral palsy / B. J. Hoare, M. A. Wallen, M. N. Thorley [et al.] // The Cochrane database of systematic reviews. - 2019. - Vol. 4. - No. 4.- CD004149. https://doi. org/10.1002/14651858.CD004149.pub3. та GMFM. Водночас при проведенні метааналізу потрібно використовувати методику PRISMA. Важливо зазначити позитивну роль, яку відіграють мотиваційні та психологічні аспекти при роботі з дітьми з ДЦП.

7. The Effectiveness of Hippotherapy to Recover Gross Motor Function in Children with Cerebral Palsy: A Systematic Review and Meta-Analysis / L. Guindos-Sanchez, D. LucenaAnton, J. A. Moral-Munoz [et al.] // Children (Basel, Switzerland). - 2020. - Vol. 7, No. 9. - P. 106. https://doi. org/10.3390/children7090106.

8. Ren Z. The Effect of Virtual Reality Games on the Gross Motor Skills of Children with Cerebral Palsy: A Meta-Analysis of Randomized Controlled Trials / Z. Ren, J. Wu // International journal of environmental research and public health. 2019. - Vol. 16, No. 20. - P. 3885. https://doi.org/10.3390/ ijerph16203885.

9. Effectiveness of virtual reality in children and young adults with cerebral palsy: a systematic review of randomized controlled trial / J. V. Fandim, B. T. Saragiotto, G. Porfírio, R. F. Santana // Brazilian journal of physical therapy. 2020. - Vol. 53, No. 20. - P. S1413-3551132-1. Advance online publication. https://doi.org/10.1016/j.bjpt.2020.11.003.

10. Alamer A. Effectiveness of Action Observation Training on Upper Limb Motor Function in Children with Hemiplegic Cerebral Palsy: A Systematic Review of Randomized Controlled Trials / A. Alamer, H. Melese, B. Adugna // Pediatric health, medicine and therapeutics. - 2020. - Vol. 11. P. 335-346. https://doi.org/10.2147/PHMT.S266720.

11. Effect of action observation therapy on motor function in children with cerebral palsy: a systematic review of randomized controlled trials with meta-analysis / N. Abdelhaleem, S. Taher, M. Mahmoud [et al.] // Clinical rehabilitation. - 2021. - Vol. 35, No. 1. - P. 51-63. https:// doi.org/10.1177/0269215520954345. 